\title{
De la gestion des déchets radioactifs : le grand débat national de 2019
}

Les défis de la gestion des déchets radioactifs sont l'objet d'un débat public et de la consultation des parties prenantes qui se déroulent sous l'égide de la Commission nationale du débat public pour définir le $5^{\mathrm{e}}$ plan national triennal de gestion des matières et des déchets radioactifs (PNGMDR).

Dans la continuité de notre politique éditoriale, nous publions dans ce numéro de Radioprotection deux articles sur les déchets radioactifs qui ouvrent de nouvelles perspectives ou revisitent des questions anciennes et laissent espérer de nouvelles solutions.

Un premier article de J. Repussard est intitulé «Que faire des déchets TFA issus des opérations de démantèlement des sites nucléaires? Les sujets de débat». Le démantèlement des sites nucléaires français produira des quantités énormes de déchets radioactifs qui dépasseront les capacités actuelles du site de stockage de l'Andra. En conséquence, l'auteur propose de revisiter à la fois la définition du déchet radioactif de très faible activité et la façon de le gérer dans une approche graduée après une analyse appropriée des risques.

Un deuxième article de G. Mercadal est intitulé «La gestion des déchets radioactifs à vie longue : confiés à l'argile ou bien gérés par la société ?». L'auteur rappelle les termes du débat national précédent de 2005-2006 au sujet du projet CiGEO de stockage géologique profond des déchets radioactifs ultimes de longue période. Comme alternative à un stockage géologique rapide, le débat avait ouvert à cette époque l'idée qu'un entreposage temporaire de surface pourrait être utile pour construire la confiance nécessaire entre la société et les décideurs. Cette proposition alternative avait été ignorée. Cet article revisite aujourd'hui cette proposition alternative et sa pertinence dans le débat public en cours.

Le débat national n'épuisera pas les questions soulevées par la gestion des déchets radioactifs et des articles à ce sujet sont les bienvenus dans Radioprotection.

Enfin je voudrais remercier chaleureusement C. Murith qui a servi pendant de nombreuses années comme éditeur international. Nous souhaitons la bienvenue à notre collègue suisse Sybille Estier qui vient de rejoindre notre comité éditorial.

\section{On the management of radioactive waste: the 2019 French national debate}

The challenges of radioactive waste management are the subject of the public debate and the consultation with stakeholders that are currently running under the aegis of the French National Commission for Public Debate in order to define the next threeyear national plan for the management of radioactive materials and waste.

In line with our editorial policy, we are publishing in this Radioprotection issue two articles on radioactive wastes that open up new perspectives or revisit old issues and offer hope for new solutions.

A first article by J. Repussard is entitled "What to do with low level radioactive waste from the dismantling of nuclear plants? Issues for debate". The dismantling of French nuclear sites will produce huge volumes of radioactive waste that will exceed the current capacity of the Andra storage site. Consequently, the author proposes to revisit both the definition of the low level radioactive waste and the way it is managed in a graded approach after an appropriate risk analysis.

A second article by G. Mercadal is entitled "The management of long life radioactive waste: entrusted to the clay vs managed by the society?" The author recalls the previous national debate in 2005-2006 on the CiGEO project for the deep geological disposal of long-term ultimate radioactive waste. As an alternative to rapid geological storage, the debate opened at that time the idea that temporary surface storage could be useful in building the necessary trust between society and decision makers. The alternative proposal has been ignored. This article revisits this proposal and its relevance in the ongoing public debate.

The French national debate will not exhaust the issues raised by management of radioactive waste and articles on this subject are welcome in Radioprotection.

Finally, I would like to thank warmly our colleague C. Murith who served for many years as an international editor. We now welcome our Swiss colleague Sybille Estier who has just joined our editorial board. 